\title{
ANALISIS NPM, ROA, DAN ROE DALAM MENGUKUR KINERJA KEUANGAN
}

\author{
Slamet Heri Winarno \\ Universitas Bina Sarana Informatika \\ Jalan Kamal Raya No.18, Ringroad Barat, Cengkareng, Jakarta Barat, Indonesia \\ slamet.smh@bsi.ac.id
}

\begin{abstract}
This research aims to determine the financial performance of an expedition company based on company profitability analysis. Indicators of profitability used include the ratio of Net Profit Margin (NPM), Return On Assets (ROA) and Return On Equity (ROE) in 2016 to 2018. Assessment of company performance is done by comparing the rentability ratio with the average ratio Industry and Bank Indonesia standards. The data used are financial statement data that is balance sheet and income statement report for year 2014 until 2016. Result of research indicate that overall rentability performance show good value, but compared with industry average performance of NPM year 2014 show less result Good, while ROA and ROE performance during 2015 and 2016 has not shown satisfactory results because it is below the industry average. Overall financial performance of the company can be said good.
\end{abstract}

Keywords: Analysis, NPM, ROA, ROE, Finance Performance

\section{PENDAHULUAN}

Dampak dari perubahan zaman dewasa ini ditandai dengan munculnya era globalisasi yang telah merubah tatanan perekonomian dunia khususnya di Indonesia. Perkembangan teknologi dan informasi dipandang sebagai suatu yang mampu merubah kondisi ekonomi global juga pada tatanan keuangan perusahaan. Kinerja perusahaan seakan menjadi taruhan agar perusahaan mampu survive dan bertahan dalam derasnya pasar global ini. Hal ini tenpu berdampak pula pada pola pengelolan keuangan perusahaan, perusahaan yang memiliki kinerja keuangan yang baik diyakini akan mampu menghadapi persaingan di era global ini dan mampu pula pengembangkan usahanya.

Pengelolaan terhadap keuangan perusahaan merupakan sesuatu yang dianggap ssangat krusial dan pentung karena akan berdampak pada kelangsungan kegiatan dan eksistensi suatu perusahaan, dan juga berpengaruh pada setiap individu yang ada dalam perusahaan tersebut. Seorang manajer keuangan dituntut untuk dapat menjalankan 
fungsi keuangan dengan baik, agar perusahaan dapat melaksanakan kegiatan operasional perusahaan dengan lebih efektif dan efisien. Selain itu dibutuhkan pula analisis terhadap laporan keuangan untuk mengetahui kemampuan perusahaan dalam mengatasi masalah-masalah keuangan agar mengambil keputusan yang cepat dan tepat. Melalui analisis tersebut, akan dapat diketahui posisi keuangan, kinerja keuangan dan kekuatan keuangan yang dimiliki perusahaan (Komala, 2013). Begitu pentingnya analisis laporan keuangan ini, sehingga perlu adanya kajian tersendiri tentang bagaimana mengukur keberhasilan dan kinerja perusahaan dalam mengelola sektor keuangannya. Tujuan dari penelitian ini antara lain: (1) untuk mengetahui bagaimana perhitungan dari Net Profit Margin, Return On Asset dan Return On Equity, (2) untuk mengetahui perbandingan Net Profit Margin, Return On Asset dan Return On Equity dalam kurun waktu tertentu, dan (3) untuk mengetahui kinerja keuangan berdasarkan indikator keuangan (Warren, 2017).

Sebagai perusahaan yang bergerak dalam bidang pengiriman barang, PT Angkasa Jaya Sejatra memiliki tujuan yaitu menjadi perusahaan yang ternama dan mampu menghasilkan keuntungan (laba) yang optimal. Diperlukan upaya penetapan strategi agar perusahaan mampu bersaing dengan perusahaan jasa ekspedisi lainnya. Selain bertujuan untuk memperoleh laba, perusahaan jasa ini juga memiliki tujuan menjadi sektor usaha yang dapat menghasilkan penilaian yang bermutu tinggi dan profesional.

Dalam konteks pemasaran jasa tidak mudah untuk menghasilkan laba yang besar, hal inilah yang menyebabkan pihak manajemen di tuntut untuk mampu menilai kondisi dan perkembangan perusahaan melalui analisis kinerja laporan keuangan agar dapat mempertahankan keberadaan perusahaan dan mampu meningkatkan pertumbuhan perusahaan di tengah pertumbuhan ekonomi yang semakin pesat dan persaingan usaha yang semakin ketat.

\section{KAJIAN LITERATUR}

\subsection{Laporan Keuangan}

Laporan keuangan sebagai alat yang sangat penting untuk memperoleh informasi sehubungan dengan adanya keinginan pihak-pihak tertentu yang berkepentingan terhadap laporan keuangan tersebut. Laporan keuangan (Myer dalam Munawir (2007:5) adalah dua daftar yang disusun oleh akuntan pada akhir periode 
untuk suatu perusahaan. Kedua daftar itu adalah daftar neraca atau posisi keuangan dan daftar pendapatan atau daftar laba rugi. Pada waktu akhir-akhir ini sudah menjadi kebiasaan bagi perseroan-perseroan untuk menambahkan daftar ketiga yaitu daftar surplus atau daftar laba yang tak di bagikan (laba yang di tahan).

Laporan keuangan menggambarkan kondisi keuangan dan hasil usaha suatu perusahaan pada saat tertentu atau jangka waktu tertentu. Adapun jenis laporan keuangan yang lazim dikenal adalah neraca atau laporan laba/rugi, atau hasil usaha, laporan arus kas dan laporan perubahan posisi keuangan (Harahap, 2007:105).

Di sisi lain, Kasmir (2008:7) berpendapat bahwa laporan keuangan adalah laporan yang menunjukkan kondisi keuangan perusahaan pada saat ini atau dalam suatu pada periode tertentu. Sedangkan Sutrisno (2007:9) menjelaskan laporan keuangan merupakan hasil akhir dari proses akuntansi yang meliputi dua laporan utama yakni, (1) neraca dan (2) laporan laba/rugi.

Analisa atas laporan keuangan pada hakikatnya adalah untuk mengadakan penilaian atas keadaan keuangan atau posisi keuangan perusahaan pada suatu saat dan perubahan posisi keuangan atau kemajuan-kemajuan suatu perusahaan melalui laporan keuangan yang bersangkutan.

\subsection{Analisis Laporan Keuangan}

Analisis laporan keuangan merupakan salah satu cara untuk mengetahui perkembangan kinerja keuangan suatu perusahaan. Dalam melakukan analisis laporan keuangan memerlukan suatu ukuran tertentu untuk mengetahui tingkat perkembangan kinerja dari suatu perusahaan.

Harahap (2007:209) menegaskan kegiatan yang selalu lazim dilakukan dalam analisis laporan keuangan dari berbagai teknik yang akan dilakukan adalah: (1) menghitung rasio, indeks, perbedaan, kenaikan, penurunan atau persentase; (2) membandingkan laporan keuangan baik dengan menggambarkannya, membuat indeks, membuat angka asli. Angka ini dibandingkan dengan periode sebelumnya, perusahaan sejenis, industrial norm (rasio rata-rata industri); (3) menilai angka-angka kenaikan, perbedaan dengan lainnya, penurunan atau rasio lainnya; (4) menganalisis hubungan satu sama lain atau mencari kemungkinan penyebab persoalan yang menyebabkan perbedaan penurunan/kenaikan; (5) menghubungkan antara satu data dengan data lain, baik antara data kuantitatif dengan data kualitatif misalnya antara kenaikan penjualan 
dengan kenaikan biaya. Antara data kuantitatif dengan data kualitatif, misalnya antara angka penjualan dengan kondisi ekonomi nasional; (6) menggunakan model atau rumus-rumus tertentu dengan menggunakan metode interpelasi, mengujinya sekaligus melihat hasilnya dan membandingkannya dengan kenyataan yang terjadi.

\subsection{Analisis Rasio Keuangan}

Rasio keuangan merupakan angka yang diperoleh dari hasil perbandingan dari satu pos laporan keuangan dengan pos lainnya yang relevan dan signifikan. Rasio keuangan ini hanya menyederhanakan informasi yang menggambarkan hubungan antara pos tertentu dengan pos lainnya. Sehingga kita dapat membeberkan informasi dan memberikan penilaian.

Rasio yaitu angka yang diperoleh dari hasil perbandingan dari satu pos laporan keuangan dengan pos yang lainnya yang mempunyai hubungan yang relevan (Munawir, 2007:64). Selanjutnya Sutrisno (2007:214) mengatakan bahwa analisis rasio keuangan adalah menghubungkan elemen-elemen yang ada dilaporan keuangan agar bisa di interprestasikan lebih lanjut". Dengan demikian analisis rasio keuangan berguna untuk menentukan kesehatan atau kinerja keuangan perusahaan baik pada sekarang maupun dimasa yang mendatang, sehingga sebagai alat untuk menilai posisi keuangan perusahaan dalam satu periode tertentu.

Setiap kegiatan bisnis mempunyai tujuan akhir yang ingin dicapai suatu perusahaan yang terpenting adalah memperoleh laba atau keuntungan yang maksimal. Rasio profitabilitas menurut Sutrisno (2007:222) adalah rasio yang menunjukkan kemampuan suatu perusahaan untuk mengukur seberapa besar tungkat keuntungan yang dapat diperoleh. Sedangkan Munawir (2007:33) menjelaskan profitabilitas adalah menunjukkan kemampuan perusahaan untuk menghasilkan laba selama periode tertentu, sehingga rasio profitabilitas adalah rasio yang dapat digunakan untuk mengukur kemampuan suatu perusahaan memperoleh laba.

Rasio profitabilitas dapat diklasifikasikan menjadi beberapa bagian, yaitu: (1) Net Profit Margin (NPM), merupakan keuntungan penjualan setelah menghitung seluruh biaya dan pajak penghasilan dengan penjualan. Harahap (2007:304), menyebutkan bahwa rasio ini menunjukkan berapa besar presentase pendapatan bersih yang diperoleh dari setiap penjualan. Semakin besar rasio ini semakin baik dianggap kemampuan perusahaan dalam mendapatkan laba cukup tinggi. Net profit margin 
merupakan ukuran keuntungan dengan membandingkan antara laba setelah bunga dan pajak dibandingkan dengan penjualan (Kasmir, 2009:200)

$$
N P M=\frac{\text { Laba Bersih }}{\text { Penjualan Bersih }} \times 100 \%
$$

(2) Return On Asset (ROA), mengukur pengembalian atas total aktiva setelah bunga dari pajak, hasil pengembalian total aktiva menunjukkan kinerja manajemen dalam menggunakan aktiva perusahaan untuk menghasilkan laba. Sugiono (2009:80-81) menegaskan Return On Asset merupakan rasio yang mengukur tingkat pengembalian dari bisnis atas seluruh aset yang ada atau rasio yang menggambarkan efisiensi pada dana yang digunakan dalam perusahaan. Semakin tinggi ROA, berarti perusahaan semakin mampu mendayagunakan aset dengan baik untuk memperoleh keungtungan.

$$
R O A=\frac{\text { Laba Bersih }}{\text { Total Aktiva }} \times 100 \%
$$

(3) Return On Equity (ROE), memperlihatkan sejauh mana perusahaan mengelola modal sendiri secara efektif, mengukur tingkat keuntungan dari investasi yang telah dilakukan pemilik modal sendiri atau pemegang saham perusahaan. Semakin besar rasio ini semakin baik. Sugiono (2009:81) mengemukakan bahwa rasio ini mengukur tingkat pengembalian dari bisnis atas seluruh modal yang ada. ROE merupakan salah satu indikator yang digunakan oleh pemegang saham untuk mengukur keberhasilan bisnis yang dijalani.

$$
R O E=\frac{\text { Laba Bersih }}{\text { Ekuitas }} \times 100 \%
$$

\subsection{Kinerja Keuangan}

Untuk memutuskan suatu badan usaha atau perusahaan memiliki kualitas yang baik, maka ada dua penilaian yang paling dominan yang dijadikan dasar acuan untuk melihat badan usaha tersebut menjalankan suatu kaidah-kaidah manajemen yang baik. Kinerja keuangan melihat pada laporan keuangan yang dimiliki oleh perusahaan yang bersangkutan. Bastian (2006:317) mengatakan kinerja adalah gambaran tingkat pencapaian pelaksanaan suatu kegiatan/program/kebijaksanaan dalam mewujudkan 
sasaran, tujuan visi dan misi organisasi yang tertuang dalam perumusan skema strategi (strategic planning) suatu organisasi.

Sedangkan Munawir (2010:30), Kinerja keuangan perusahaan merupakan satu diantara dasar penilaian mengenai kondisi keuangan perusahaan yang dilakukan berdasarkan analisa terhadap rasio keuangan perusahaan. Pihak yang berkepentingan sangat memerlukan hasil dari pengukuran kinerja keuangan perusahaan untuk dapat melihat kondisi perusahaan dan tingkat keberhasilan perusahaan dalam menjalankan keberhasilan perusahaan dalam menjalankan kegiatan operasionalnya.

Kinerja setiap perusahaan berbeda-beda karena ruang lingkup bisnis yang dijalankan. Terdapat lima tahap dalam menganalisis kinerja keuangan Fahmi (2011:3), yaitu: (1) melakukan review terhadap terhadap laporan keuangan, review disini diajukan dengan tujuan agar laporan keuangan yang sudah dibuat tersebut sesuai dengan penerapan kaidah-kaidah yang berlaku umum dalam dunia akuntansi, sehingga dengan demikian hasil laporan keuangan dapat dipertanggungjawabkan; (2) melakukan perhitungan, penerapan metode perhitungan disini adalah disesuaikan dengan kondisi permasalahan yang sedang dilakukan sehingga hasil perhitungan tersebut akan memberikan suatu kesimpulan sesuai dengan analisis yang di inginkan; (3) melakukan perbandingan terhadap hasil hitungan yang telah diperoleh, dari hasil perhitungan yang sudah diperoleh tersebut, kemudian dilakukan perbandingan dengan hasil hitungan dari berbagai perusahaan lainnya. Metode yang paling umum digunakan untuk melakukan perbandingan ini ada dua, yaitu: Time series analysis dan Cross sectional approach; (4) melakukan penafsiran terhadap berbagai permasalahan yang ditemukan, pada tahap ini analisis melihat kinerja keuangan perusahaan adalah setelah dilakukan ketiga tahapan tersebut, selanjutnya dilakukan penafsiran untuk melihat masalah-masalah yang dialami perusahaan; (5) mencari dan memberikan pemecahan masalah terhadap permasalahan yang ditemukan, pada tahap terakhir, setelah ditemukan berbagai permasalahan yang dihadapi maka dicarikan solusi guna memberikan suatu input agar apa yang menjadi kendala bisa diatasi.

Untuk menilai kinerja keuangan dan prestasi perusahaan, analisis keuangan merupakan tolak ukur yaitu rasio yang menghubungkan dua data keuangan yang satu dengan yang lainnya. Analisis dari macam-macam rasio dapat memberikan pandangan yang lebih baik mengenai kondisi perusahaan dan prestasi perusahaan. Dengan 
menggunakan alat analisis berupa rasio akan dapat menjelaskan atau memberikan gambaran tentang posisi keuangan perusahaan terutama apabila angka rasio pembanding yang digunakan sebagai standar.

Hasil pengukuran kinerja kerja dapat dijadikan sebagai alat evaluasi kinerja manajemen selama ini, apakah mereka telah bekerja secara efektif atau tidak. Kegagalan atau keberhasilan dapat dijadikan sebagai bahan acuan untuk perencanaan laba kedepan, sekaligus kemungkinan untuk menggatikan manajemen yang baru terutama setelah manajemen lama mengalami kegagalan. Oleh karena itu rasio profitabilitas ini sering disebut sebagai salah satu alat kinerja manajemen (Kasmir, 2008:197).

Indikator pengukuran kinerja berdasarkan kriteria NPM, ROA dan ROE menurut Kasmir (2008:201), yaitu: (1) perusahaan dikatakan baik jika NPM yang dimiliki di atas rata-rata industri pada umumnya yakni 20\%; (2) perusahaan dikatakan baik jika mampu mencapai ROA di atas rata-rata industri untuk yaitu 30\%; (3) perusahaan dikatakan baik jika ROE yang dimiliki oleh perusahaan di atas rata-rata industri.pada umumnya yakni rata-rata 40\%. Sedangkan Bank Indonesia menetapkan standar kinerja keuangan yang tercantum dalam Peraturan Bank Indonesia No. 6/10/PBI/2004, sebagai berikut:

Tabel 1. Standar Rasio Berdasarkan Peraturan Bank Indonesia

\begin{tabular}{|l|c|}
\hline \multicolumn{1}{|c|}{ Rasio } & Standar Bank Indonesia \\
\hline Net Profit Margin (NPM) & $3 \%-9.5 \%$ \\
\hline Return On Asset (ROA) & $0.5 \%-1.25 \%$ \\
\hline Return On Equity (ROE) & $5 \%-12.5 \%$ \\
\hline
\end{tabular}

Sumber: Bank Indonesia

\section{METODE PENELITIAN}

Penelitian ini merupakan analisis kuantitatif yang mencoba menunjukkan pengukuran kinerja keuangan melalui analisis rasio NPM, ROA dan ROE. Data-data yang digunakan adalah data sekunder yang berasal dari laporan keuangan salah satu perusahaan yang bergerak dalam bidang pengiriman barang (ekspedisi), yaitu PT Angkasa Jaya Sejatra sebagai sampel penelitian untuk tahun 2016-2018.

Pengukuran variabel penelitian menggunakan teknik analisis perbandingan guna mengetahui tingkat kinerja masing-masing variabel, jika dibandingkan dengan suatu standar pengukuran. 


\section{HASIL PENELITIAN DAN PEMBAHASAN}

\section{a. Perhitungan Indikator NPM, ROA dan ROE}

Guna mengukur kinerja keuangan perusahaan maka perlu diukur indikator atau instrumen keuangan yang akan digunakan, instrumen tersebut adalah pos-pos keuangan yang ada pada laporan keuangan baik neraca dan laporan laba/rugi yang diperoleh dari annual report perusahaan. Berdasarkan data-data pada kedua laporan tersebut akan dihasilkan nilai dari total asset, total modal serta total laba bersih untuk beberapa periode. Periode yang digunakan pada penelitian ini yaitu data keuangan untuk tahun 2016 hingga 2018, seperti pada tabel 2.

Tabel 2. Ringkasan Laporan Keuangan 2016-2018 (dalam rupiah)

\begin{tabular}{|l|c|c|c|}
\hline \multicolumn{1}{|c|}{ Uraian } & 2016 & 2017 & 2018 \\
\hline Total Aktiva & $806.353 .635,38$ & $833.940 .514,33$ & 871.809 .390 .57 \\
\hline Total Modal & $642.547 .642,38$ & $726.028 .269,33$ & 838.374 .429 .57 \\
\hline $\begin{array}{l}\text { Pendapatan } \\
\text { Bersih }\end{array}$ & $5.185 .059 .500,00$ & 3.822 .256 .800 .00 & 3.385 .541 .650 .00 \\
\hline Laba Bersih & $122.997 .524,62$ & 133.480 .626 .95 & 112.346 .160 .24 \\
\hline
\end{tabular}

Sumber: Laporan Neraca Dan Rugi Laba

Berdasarkan Tabel 2, pada pos total aktiva terjadi kenaikan selama 3 tahun terakhir dengan tingkat kenaikan rata-rata 3,5\% tiap tahunnya. Kenaikan ini dapat disebabkan oleh kenaikan disisi current asset perusahaan, yaitu banyak uang tunai (kas) yang ada di perusahaan. Di sisi lain, modal perusahaan menunjukkan trend yang positif dimana terjadi kenaikan sebesar 13\% tahun 2017 dan 15,5\% tahun 2018.

Sedangkan dari sisi tingkat net income, perusahaan mengalami penurunan dalam 3 tahun tersebut, penurunan ini disebabkan karena perbandingan antara pendapatan bruto dan seluruh pengeluaran perusahaan menunjujjan hasil yang negatif. Hal ini pula yang menyebabkan jumlah laba bersih (profit) juga mengalami trend yang turun naik dari tiga periode tersebut. Berdasarkan data keuangan tersebut, tahap selanjutmya adalah melakukan perhitungan kinerja keuangan perusahaan dengan menggunakan rasio Net Profit Margin, Return On Asset dan Return On Equity seperti pada bagian sebelumnya. Hasil dari perhitungan ditunjukkan pada tabel 3. 
Tabel 3.

Rasio Profitabilitas

\begin{tabular}{|l|l|l|l|}
\hline \multirow{2}{*}{ Rasio } & \multicolumn{3}{|c|}{ Tahun } \\
\cline { 2 - 4 } & \multicolumn{1}{|c|}{2016} & \multicolumn{1}{c|}{2017} & 2018 \\
\hline NPM & $2.37 \%$ & $3.49 \%$ & $3.32 \%$ \\
\hline ROA & $15.25 \%$ & $16.01 \%$ & $12.89 \%$ \\
\hline ROE & $19.14 \%$ & $18.39 \%$ & $13.40 \%$ \\
\hline
\end{tabular}

Sumber : data diolah

Net Proffit Margin (NPM) adalah merupakan keuntungan penjualan setelah perhitungan biaya dan pajak penghasilan (Warren, 2017) Marjin ini menunjukan perbadingan laba setelah pajak dengan penjualan. Semakin tinggi NPM, semakin baik operasi suatu perusahaan. Berdasarkan tabel 3, maka dapat dilihat bahwa pada tahun 2016 nilai NPM sebesar 2.37\%, hal ini mengindikasikan bahwa setiap Rp. 1 penjualan akan menghasilkan keuntungan neto yaitu Rp. 0.0237, sedangkan pada tahun 2017 NPM meningkat menjadi 3.49\%, ini berarti bahwa setiap Rp. 1 penjualan akan menghasilkan keuntungan neto yaitu Rp. 0.0349. Namun pada tahun 2018 terjadi turun menjadi 3.32\%, ini berarti bahwa setiap Rp. 1 pejualan akan menghasilakan keuntungan neto yaitu Rp. 0.0332. Kemampuan dari perusahaan dalam meningkatkan jumlah pendapatannya di tiap periode sedikit banyak akan mempengaruhi kenaikan dan penurunan dari NPM.

Sedangkan Return On Asset (ROA), merupakan kemampuan perusahaan secara keseluruhan didalam menghasilkan keuntungan dengan jumlah aktiva yang tersedia didalam perusahaan (Komala, 2013). Semakin tinggi rasio ini semakin baik keadaan perusahaan. Pada tabel 3, hasil perhitungan analisis ROA, maka dapat dilihat bahwa pada tahun 2016 nilai ROA sebesar 15.25\%, tahun 2017 sebesar $16.01 \%$ dan pada tahun 2018 sebesar 12.89\%. Hal ini menunjukkan bahwa penggunaan seluruh aktiva oleh perusahaan telah berhasil menghasilkan laba bersih secara optimal walaupun pada tahun 2016 terjadi penurunan. Angka rasio ini puka menunjukkan kemampuan perusahaan dalam menghasilkan laba berfluktuasi. Kondisi ini menunjukkan bahwa penggunaan aktiva perusahaan belum sepenuhnya efisien dan naik turunnya tingkat laba yang dihasilkan oleh keseluruhan penggunaan aktiva.

Disisi lain, Return On Equity (ROE) merupakan suatu pengukuran dan penghasilan yang tersedia bagi para pemihak maupun perusahaan (baik pemegang 
saham biasa maupun pemegang saham preferen) atas modal yang mereka investasikan didalam perusahaan. Semakin tinggi penghasilan yang diperoleh semakin baik keadaan perusahaan. Dari hasil perhitungan, maka dapat dilihat Return On Equity pada tahun 2016 sebesar 19.14\%, tahun 2017 sebesar $18.39 \%$ dan pada tahun 2018 sebesar 13.4\%. Hal ini berarti bahwa penggunaan seluruh kemampuan modal sendiri untuk menghasilkan keuntungan neto selama tiga periode tersebut dapat dikatakan optimal walaupun terdapat penurunan pada tahun 2016, hal ini biasanya disebabkan oleh terjadinya penurunan investasi pada modal perusahaan.

\section{b. Penilaian Kinerja Keuangan}

Kinerja keuangan adalah usaha yang dilakukan oleh perusahaan yang dapat mengukur keberhasilan perusahaan dalam menghasilkan laba, sehingga dapat melihat pertumbuhan dan potensi perkembangan perusahaan yang baik. Suatu perusahaan dapat dikatakan berhasil apabila telah mencapai standar dan tujuan yang telah ditetapkan. Pengukuran kinerja keuangan dapat dilakukan dengan membandingkan antara rasio profitabilitas yang dihasilkan dengan rasio dari rata-rata industri dan standar yang berlaku dari Bank Indonesia, seperti tersaji pada tabel 4. Dari hasil penelitian, kinerja keuangan terhadap perusahaan yang bergerak dalam bidang ekspedisi ini dapat dilihat pada tabel 4 .

Tabel 4. Hasil Kinerja Keuangan

\begin{tabular}{|l|r|r|r|c|c|}
\hline \multirow{2}{*}{ Rasio } & \multicolumn{3}{|c|}{ Tahun } & Rata-rata Industri & \multirow{2}{*}{ Standar BI } \\
\cline { 2 - 5 } & 2016 & 2017 & 2018 & & $3 \%-9.5 \%$ \\
\hline NPM & $2.37 \%$ & $3.49 \%$ & $3.32 \%$ & $3.06 \%$ & $0.5 \%-1.25 \%$ \\
\hline ROA & $15.25 \%$ & $16.01 \%$ & $12.89 \%$ & $14.72 \%$ & $5 \%-12.5 \%$ \\
\hline
\end{tabular}

Sumber : data diolah

Penilaian kinerja keuangan dapat dianalisis dengan metode komparasi antara kinerja keuangan yang dihasilkan dengan standar kinerja yang berlaku baik yang berasal dari rata-rata industry dan yang berasal dari standar Bank Indonesia. Pada tabel 4, kita dapat membandingkan nilai dari masing-masing variabel atau indikator keuangan (NPM, ROA dan ROE) untuk tiap-tiap tahunnya.

Dari sisi NPM, terlihat bahwa nilai-nilai yang dihasilkan tiap tahunnya mengalami fluktuasi, jika nilai dari kinerja indikator profitabilitas ini dibandingkan 
dengan kinerja rata-rata industri didapati kinerja tahun 2017 dan 2018 dinilai baik (sehat) dengan nilai $3.49 \%$ dan $3.32 \%$ diatas nilai rata-rata industri $3.06 \%$. Hanya pada tahun 2016 kinerja keuangan perusahaan dinilai kurang baik karena nilai NPM sebesar $2.37 \%$ dibawah rata-rata industri 3.06\%. Jika dibandingkan dengan standar kinerja dari Bank Indonesia, kinerja keuangan tahun 2017 dan 2018 dapat dikatakan baik/sehat karena berada dikisaran 3\% - 9.5\%. Sedangkan untuk tahun 2016, nilai kinerja keuangan masih dikatakan belum baik karena dibawah kisaran 3\% - 9.5\%. Kurang baiknya kinerja keuangan ditahun 2016 ini dapat disebabkan oleh faktor jumlah laba yang diperoleh dibandingkan dengan pendapatan.

Kinerja keuangan ROA selama tahun 2016 dan 2017 dapat dikatakan cukup baik/sehat karena berada diatas rata-rata industri sebesar $14.72 \%$, namun disisi lain nilai ROA tahun 2018 berada dibawah rata-rata industri yaitu sebesar $12.89 \%$. Hal ini menunjukkan kurang optimalnya perusahaan dalam management asset yang berdampak pada jumlah laba yang diperoleh pada tahun tersebut. Namun kinerja secara keseluruhan dari indikator ROA selama 2016-2018 jika dibandingkan dengan standar BI menunjukkan hasil yang sangat baik karena berada diatas kisaran 0.5\% - 1.25\%.

Penilaian kinerja yang menyangkut bagaimana pengelolaan terhadap setiap investasi modal perusahaan dalam menghasilkan laba (ROE) menunjukkan trend yang baik sepanjang tahun 2016-2018. Hal ini dapat terlihat dari perbandingan nilai ROE pada dua tahun tersebut yang berada diatas rata-rata industri dan standar BI, yang menunjukkan pula bahwa upaya pengelolaan investasi yang dilakukan oleh perusahaan terbukti telah efektif dalam menghasilkan keuntungan. Hanya pada tahun 2018 kinerja keuangan ROE dapat dikatakan kurang baik jika dibandingkan dengan rata-rata industri namun jika dibandingkan dengan standar BI nilai yang dihasilkan angka $13.40 \%$ berada diatas kisaran 5\% - 12.5\%. Dapat dikatakan bahwa dalam kurun waktu 2016-2018 keseluruhan kinerja keuangan khususnya kinerja profitabilitas dinyatakan baik/sehat.

\section{SIMPULAN DAN SARAN}

Berdasarkan hasil penelitian dan analisis data penilaian kinerja keuangan NPM, ROA dan ROE selama tahun 2016-2018 dapat dikatakan baik, hal ini tercermin dari nilai masing-masing indikator kinerja keuangan tersebut. Nilai-nilai NPM menunjukkan bahwa perusahaan memiliki kinerja kemampulabaan yang baik, sedangkan nilai-nilai 
ROA dan ROE juga menunjukkan keoptimalan perusahaan dalam pengelolaan asset dan modalnya dalam menghasilkan keuntungan.

Penilaian kualitas dari kinerja keuangan dilakukan dengan melakukan perbandingan nilai-nilai dari NPM, ROA dan ROE dengan rata-rata industri serta standar pengukuran Bank Indonesia. Hasil penilaian memperlihatkan bahwa NPM pada tahuan 2016 menunjukkan kinerja yang kurang baik karena berada dibawah rata-rata industri 3.06\% dan dibawah standar BI pada kisaran 3\% - 9.5\%. Untuk kinerja ROA dan ROE sepanjang tahun 2016-2018 dapat dikatakan memiliki kinerja yang baik karena nilai yang dihasilkan berada diatas rata-rata industri dan standar BI, tidak demikian halnya pada tahun 2018 kinerja ROA dan ROE dikatakan kurang baik karena dibawah rata-rata industri, namun jika dibandingkan dengan standar BI dapat dikatakan memiliki kinerja yang baik.

Perlu adanya upaya dari pihak perusahaan untuk lebih meningkatkan kinerja pendapatan dengan meningkatkan kapasitas produksi atau aktivitas operasional, agar kinerja keuangan di masa mendatang.

\section{DAFTAR PUSTAKA}

Bastian, Indra. (2006). Akuntansi Sektor Publik Di Indonesia. Jakarta: Erlangga.

Fahmi, I. (2011). Pengantar Manajemen Keuangan. Bandung: Alfabeta.

Harahap, S. S. (2007). Analisis Kritis atas Laporan Keuangan, Edisi Kesatu . Jakarta: PT Raja Grafindo Persada. (2010). Analisis Kritis atas Laporan Keuangan. Jakarta: PT Raja Grafindo Persada.

Indonesia, Bank. (2017). Peraturan Bank Indonesia Nomor: 6/10/PBI/2004 Tentang Sistem Penilaian Tingkat Kesehatan Bank Umum. Diambil dari : http://jdih.bpk.go.id/wp-content/uploads/2011/03/PBI_6-10-2004_sist-PenilaianTKS-Bank.pdf (diakses tanggal 13 Juni 2017).

Kasmir. (2008). Analisis Laporan Keuangan, Edisi Pertama. Jakarta: Rajawali Pers. (2012). Analisis Laporan Keuangan, Edisi Ke 1-5. Jakarta: Rajawali Pers. 
Komala, L. A. (2013). The Effects of Profitability Ratio, Liquidity, and Debt towards Investment Return. Journal of Business and Economics ISSN 2155-7950, USA November 2013, Volume 4, No. 11, 1176-1186.

Munawir, S. (2007). Analisa Laporan Keuangan, Edisi Keempat. Jogjakarta: Liberty.

Sugiono, A. (2009). Manajemen Keuangan Untuk Praktisi Keuangan. Jakarta: Grasindo.

Sutrisno. ( 2007). Manajemen Keuangan, Teori, Konsep dan Aplikasi. Jogjakarta: Konosia.

Warren, Hans. (2017). Profitability Ratio: Definition, Formula, Analysis \& Example. 2017. Diambil dari : http://study.com/academy/lesson/profitability-ratiodefinition-formula-analysis-example.html (diakses tanggal 22 Mei 2017) 